\title{
Proteins and Their Peptide Motifs in Acellular Apatite Mineralization of Scaffolds for Tissue Engineering
}

\author{
Johan Benesch, Ph.D., ${ }^{1,2}$ João F. Mano, Ph.D., ${ }^{1,2}$ and Rui L. Reis, Ph.D. ${ }^{1,2}$
}

Many proteins in the inorganic/organic matrix of bone induce or modulate or inhibit mineralization of apatite in vivo. Many attempts have been made to mimic and understand this mechanism as part of bone formation, and ectopic mineralization and control thereof. Many attempts have also been made to use such proteins or protein fragments to harness their potential for improved mineralization. Such proteins and peptide motifs have also been the inspiration for attempts of making mimics of their structures and motifs using chemical or biological synthesis. The aim of this review is to highlight how proteins and (poly)peptides themselves impact mineralization in the human body, and how those could be used and have been used for improving apatite mineralization, for example, on or in materials that by themselves do not induce apatite mineralization but otherwise have interesting properties for use as bone tissue engineering scaffolds.

\section{Introduction}

$\mathbf{W}$ ITH THE AIM of making new bone or replacing damaged bone, many venues have been chosen in the past. With the advent of ideas that aim to enable us to replace damaged bone without resorting to metallic implants, there is a need for materials and procedures that will comply with the requirements for clinical success. For bone tissue engineering applications, it is important to develop scaffolds that are both degradable and can induce apatite formation. The overall goal should always be to achieve the three O's of bone growth and repair: osteoinduction, osteoconduction, and osteogenesis. ${ }^{1}$ Because hydroxylapatite self-induces further hydroxylapatite formation, ${ }^{2-4}$ it may be a good starting point to coat the scaffolds with a thin layer of apatite for the scaffold to be successful. A large range of inorganic chemical modification (e.g., using silicate treatments) strategies drawing inspiration from the Nature for coating biomaterials with calcium phosphates in vitro have been attempted. ${ }^{5}$ Indeed, it has been claimed that the essential requirement for an artificial material to bond to living bone is the presence of apatite or the formation of biologically active bone-like apatite layer on their surfaces, ${ }^{6}$ although highly crystalline stoichiometric hydroxylapatite is probably not the best option for tissue-engineered constructs because of its low solubility. ${ }^{7}$ One should note that cells bind to the implanted structures rather than implants binding to bone. ${ }^{8}$

However, there may not be enough autogenous bone or of inferior quality because of the health status of the patient to make this a viable option, ${ }^{1}$ and since xeno- or allografts usually are advised against because of the risk of transmitting disease agents, the use of autograft is usually recommended for bone repair. ${ }^{1}$ In this context, proteins or synthetic polypeptides have been suggested for induction of mineralization of constructs that are aimed at replacing damaged or weakened bone.

Because there are some differences in how the protein based mechanisms for acellular mineral nucleation and growth, many have suggested that there are two classes of inhibitors: those that affect nucleation and those that affect crystal growth. ${ }^{9,10}$ One would expect that promoters in analogy also can be divided into two classes. Perhaps, surprisingly we shall note that some proteins can be either inhibitor or promoter depending on not only its state but also experimental parameters. For in vitro experiments this can also be influenced by experimental factors such as biopolymer and ion concentration, and $\mathrm{pH}$. Thus, it is important to learn from the Nature how proteins and peptide motifs are used in vivo to induce nucleation and growth, and how they can be used to induce an appropriately formed apatite. In this review we will not focus on the cellular actions. ${ }^{11-14}$

Many proteins both in the extracellular matrix (ECM) and in blood will affect the mineralization as noted in the existing very wide and large literature. One would thus expect that it is very appealing to learn from the Nature how the mimics of the organic components in bone can be used to control mineral formation by learning how these modulate both the initial nucleation and the following crystal growth.

\footnotetext{
${ }^{1} 3 \mathrm{~B}$ 's Research Group—Biomaterials, Biodegradables, and Biomimetics, Department of Polymer Engineering, University of Minho, Caldas das Taipas, Portugal.

${ }^{2}$ IBB - Institute for Biotechnology and Bioengineering, PT Government Associated Laboratory, Braga, Portugal.
} 
This review aims to give a brief introduction to apatite and the proteins involved in mineralization followed by a more extensive account of how proteins themselves directly can influence mineralization of apatite and how that has been used to induce and modulate apatite formation for biomaterials and bone tissue engineering applications.

\section{Apatites in Bones}

There has been some debate whether the apatite in bone is hydroxyl apatite or carbonate apatite, although the apatite found in human bone is most likely poorly crystalline carbonated apatite with some hydroxyl character. ${ }^{15-19}$ The inorganic phase of bone is apatite with different crystal size and substituents depending on when and where it is formed. ${ }^{20}$ The first woven bone is biodegraded and replaced with lamellar bone that is more structured. ${ }^{11,21}$

It is not always clearly demonstrated which type of apatite is formed in the in vitro or in vivo experiments because often only the $\mathrm{Ca} / \mathrm{P}$-ratio, but neither the hydroxyl nor carbonate content, is determined. Thus, in this review the formed mineral in the referenced studies is in many cases simply referred to as apatite (at least when the determined $\mathrm{Ca} / \mathrm{P}$ ratio is between 1.6 and 2). Below that the formed pure calcium phosphate may not be apatitic ${ }^{15}$ but can be apatitic if $\mathrm{Ca}$ is partially substituted with $\mathrm{Mg}$ and other metals so that $(\mathrm{Ca}+\mathrm{Me}) / \mathrm{P}>1.6$.

\section{The Proteins}

Many proteins have multiple functions, so it is not surprising that a mineralization-related protein may have multiple functions in mineralization. ${ }^{21-37}$ Overall, many of the mineralization-related proteins are acidic and phosphorylated. Some proteins contain dicarboxylic acids. Notably, dentin phosphoprotein contains $37 \%$ aspartic acid and 38\% serine. ${ }^{38}$ Three of four amino acids are Asp and PSer motifs such as PSer-Asp-PSer-Asp, Asp-X-Asp-Y, and PSer-W-PSer-Z, where $\mathrm{X}-\mathrm{Z}$ may also be Asp or Ser. ${ }^{39}$ And phosphoryns have multiple repeats of Asp-Ser-Ser ${ }^{40}$ of which the serines often are phosphorylated. These findings suggest that alternating rather than homopolypeptides are important during mineralization in terms of calcium coordination, and apatite binding and modulation.

The differences in distribution of all these protein indicate that they have different roles in both space (specific tissues, see Table 1) and time ${ }^{20,41-45}$ because they are expressed with different timing during bone formation. But all proteins are not exclusively associated with bone; for example, biglycan and decorin are found both in bone and cartilage, although their glycosylation varies between tissues. ${ }^{46}$ And others that prevent mineralization are not found in bone; for example, saliva contains statherin. ${ }^{47,48}$ (See Table 1 for an overview of the tissue distribution of these proteins and a tentative summary of their roles in mineralization.) Collagen is the major protein in bone ${ }^{11,21}$ but does not necessarily nucleate apatite in vivo. ${ }^{49}$ Hence, one would assume that the noncollagenous bone proteins regulate bone mineralization ${ }^{50}$ although the orientation of the collagen fibrils is important for the organization of the formed bone. ${ }^{11,51}$

\section{Protein Binding to Apatite}

Many proteins will bind from blood plasma to hydroxylapatite. ${ }^{52}$ In fact, the wide difference in the ability of proteins to adsorb to apatite has been used in protein separation techniques since the $1950 \mathrm{~s} .{ }^{53}$ The binding of proteins to apatite depends on their isoelectric point. ${ }^{54,55}$ Clusters of carboxyl groups (rather than total amount of negative charges) strengthen protein binding to hydroxylapatite. ${ }^{55}$ The dicarboxyl on Gla in bone Gla protein makes it bind stronger to apatite than to amorphous calcium phosphates. ${ }^{56}$ Gla has also been shown to be vital for osteocalcin and oligopeptide mimic to bind to apatite. ${ }^{50,57,58}$

For N-terminal fragments of statherin, it is the sequence, conformation, and the total charge rather than the chemical groups that are important for its binding behavior to apatite. ${ }^{48}$ The sign of the charge is also important as demonstrated by the higher affinity ${ }^{4,59}$ to and lower elutability ${ }^{60}$ from apatite of negatively charged proteins compared to positively charged proteins (at physiological $\mathrm{pH}$ ).

A number of amino acid sequences with three carboxyls and/or phosphates have been identified and stipulated to have a role in the binding of phosphoryn to apatite. ${ }^{61} \mathrm{~A}$ Glurich region in osteonectin and bone sialoprotein and Gla in proline-rich salivary proteins have been suggested as being responsible for the binding to apatite. ${ }^{62-64}$

On the other hand, for some apatite-binding proteins only one or two phosphoserine residues are enough to increase their adsorption on apatite. ${ }^{65}$ But it has been noted that at least three amino acids are necessary to span one apatite unit cell. ${ }^{62}$ Just the presence of a long charged sequence does not necessarily mean that it is readily available for binding of calcium for either apatite nucleation or protein binding to apatite. The conformation of the polypeptide or more specifically the structure of the carboxylated and/or phosphyrolated amino acids could be just as important. ${ }^{40}$ Part of the function could be lattice matching between mineral and polymer, ${ }^{66-69}$ which is supported by data on alternating arrangements of charged domains on enamel crystal surfaces. ${ }^{70}$ Note the dimensions of the unit cell of HA: $\mathrm{a}=\mathrm{b}=9.4 \AA$, and $\mathrm{c}=6.9 \AA .{ }^{69}$

Similar results were recently noted from X-ray diffraction (XRD) data on porcine osteocalcin that yielded a good periodic match between five $\mathrm{Ca}$ ions bound at three Gla at consecutive $\alpha$-helix turns and Ca positions at the face parallel with the c-axis of hydroxylapatite. ${ }^{57}$ A synthetic oligopeptide mimicking this Gla containing $\alpha$-helix yielded good binding at the (100) face of hydroxylapatite, which was strongly dependent on the $\gamma$-carboxylation of Glu. ${ }^{58}$

Also homopolypeptides such as poly-Glu can be used to induce nanocrystalline apatite. ${ }^{71}$ However, as already mentioned, many phosphoproteins use alternating peptide sequences for binding to apatite and modulating apatite growth. This, again, stresses the role of conformation of polypeptides in relation to mineralization. The dimensions of the formed $\beta$-sheet are important because it probably is better if it matches the lattice dimensions of the mineral surface that is to be encouraged. ${ }^{72}$ For example, the periodicity of poly-Asp is 6.7-6.9 $\AA$ and would fit the c-direction of the (100) surface of octacalcium phosphate (OCP) (6.87 ̊). Also, the modeling of binding of oligopeptides to apatite or OCP indicated a better fit for $\beta$ strands comprising PSer-Asp or Pser-Pser-Asp rather than just repeats of either PSer or Asp. ${ }^{67}$ This could point at differences in the roles of electrostatic interaction and chelation in mineralization. But then carboxylated $\beta$-sheets can be induced or stabilized by $\mathrm{Ca}^{2+}$ binding $^{73}$ or adsorption to apatite. ${ }^{58}$ 


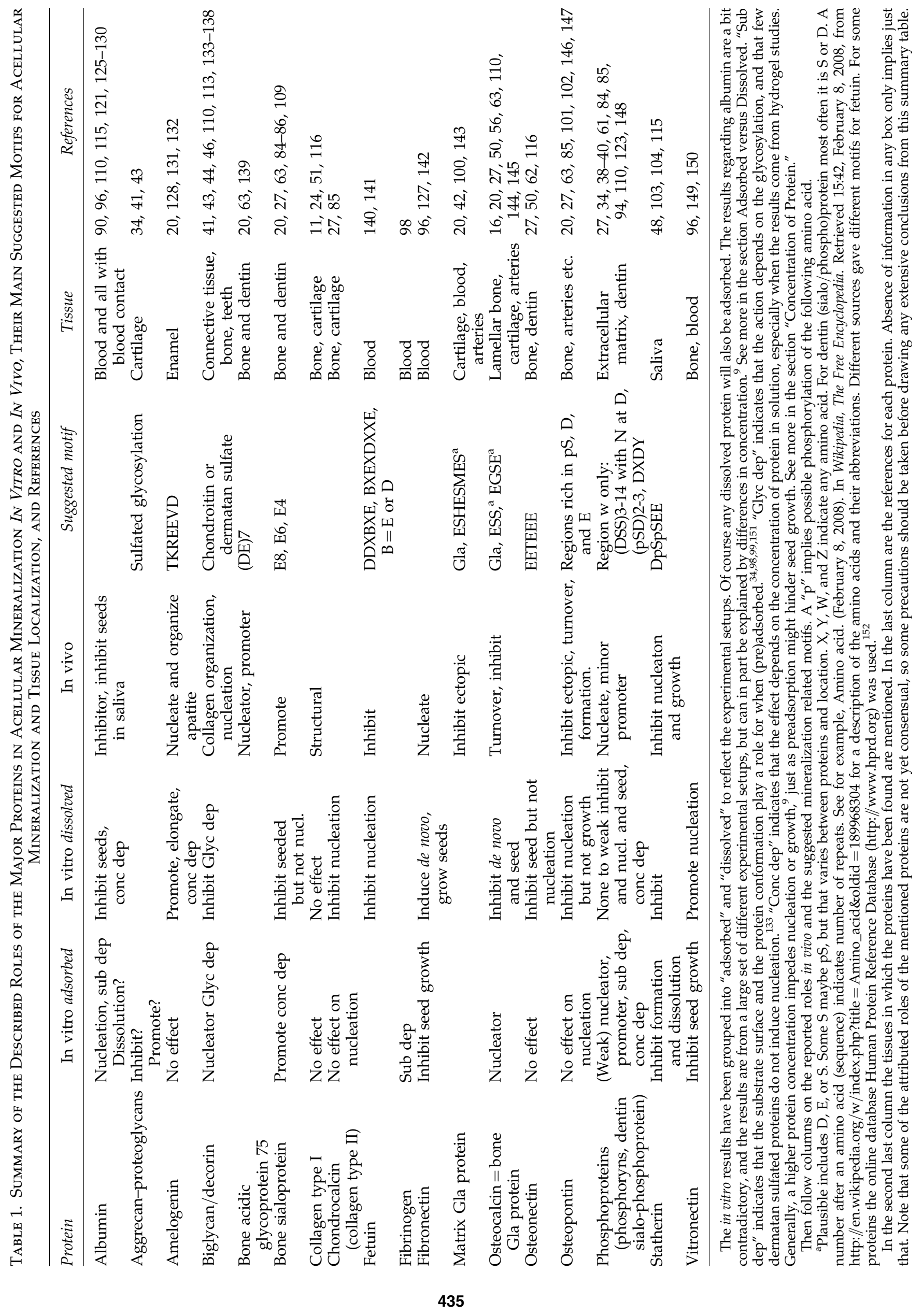


It is also important to note that apatite is known to activate both the coagulation ${ }^{74,75}$ and the complement ${ }^{76,77}$ systems. On the other hand, activation of bodily defense systems via the complement and coagulation systems has been implied to play a positive role in osseointegration. ${ }^{78}$

\section{Proteins and Apatite Formation}

The organic components of the ECM are important for both starting the mineralization by acting as seeds, and control of the growth of the crystals by influencing the density of seeds, and the orientation and organization of the formed crystals ${ }^{79,80}$ or acting as inhibitors. ${ }^{81}$ In many cases they also contribute to the strength of and stabilize the mineralized tissue. ${ }^{79}$ Apatite crystals have been detected in the grooves and channels of collagen type I. ${ }^{51,82}$ Apatite does not normally form on collagen by itself in vivo although one can grow minerals on it in vitro. ${ }^{83}$ Further, the carbonate apatite structure is tuned by the organization of the collagen type I network. ${ }^{24,51}$

The accumulation of (bone and dentine) sialoproteins in bone and dentine suggests that they have a role in the apatite mineralization in vivo. ${ }^{63,84}$ Bone sialoprotein is highly phosphorylated and rich in polyglutamic regions. Dentin sialoprotein is similar but is low in phosphorylation. Bone sialoprotein is an effective apatite nucleator in vitro ${ }^{84,85}$ in hydrogels, whereas dentin sialoprotein has a much lower affinity for apatite and only has a small effect on nucleation and growth. ${ }^{84}$ Glutamic acid (Glu)-rich regions have been attributed to the nucleation properties of bone sialoprotein. ${ }^{86}$ As reviewed by Boskey, phosphophoryn and bone sialoprotein can be both nucleators and inhibitors ${ }^{28}$ of apatite mineralization.

Osteocalcin adsorbed in the surface region of collagen/ apatite composite or apatite alone can switch on the remodeling cascade. ${ }^{87-89}$ Osteocalcin present in solution (and thus also on the surface) inhibits the nucleation and growth of apatite crystals in vitro, ${ }^{27,50,65}$ and the presence of Gla is crucial. ${ }^{50}$ But osteocalcin is probably more important for remodeling than for nucleation ${ }^{45}$ due to its late appearance during bone formation.

Preadsorbed dentin matrix protein 1 induces apatite formation on glass plates in vitro. ${ }^{90}$ Some domains undergo a shift to $\beta$-sheet conformation upon $\mathrm{Ca}$ binding that precedes mineralization. ${ }^{91}$ The $\beta$-sheets are also proposed to act as templates for mineralization. ${ }^{73}$ It would seem that the Ca ion binding also acts as an electrostatic shield that is important for this change in conformation.

Phosphophoryn in the mineralized dentin matrix is highly phosphorylated. ${ }^{40}$ It is believed to be involved in the regulation of the mineralization processes by binding to collagen, nucleating mineralization, and controlling crystal growth, ${ }^{40,61,92-95}$ and inhibits seeded growth. ${ }^{34}$

There are many proteins that are not specific for bone tissue that also take part in the formation of bone especially if they are present in the blood stream. Fibronectin and vitronectin modulate and induce de novo growth of apatite crystals when adsorbed, but inhibits apatite growth when adsorbed on already formed apatite. ${ }^{96}$ Apparently, adsorbed fibrinogen and albumin may have different effects on mineralization depending on the substrate $e^{97,98}$ that perhaps differently affect their conformation upon adsorption and also their ability to affect mineralization. The type of seed crystal has shown to be important when phosphoproteins are dissolved. ${ }^{34}$ This could be due to differences in ability to adsorb to the surfaces. Secondary structure of a protein can be important for its ability to induce apatite formation after adsorption, ${ }^{61,99}$ perhaps by providing a stiff template or chelator as starting point for nucleation.

Most of the reported posttranslational modifications that impact on the mineralization modulation ability of proteins are covered in the Supplemental Material. Overall, most of the proteins that induce or inhibit apatite nucleation and/or growth contain clusters of negatively charged groups like sulfate, carboxyl, and phosphate that act via electrostatic interaction to attract or coordinate calcium ions at apatite surfaces, in solution and adsorbed.

\section{Ectopic mineralization}

Mineralization in soft tissue is in most case not functional and can be lethal especially if it persists in the arteries. So an active control seems to be of vital importance. To curb ectopic mineralization there are a number of control proteins such as matrix Gla protein, ${ }^{42,100}$ osteopontin, ${ }^{40,101,102}$ and statherin. ${ }^{48,64,103,104}$ The sulfated saccharides on soft tissue proteoglycans have been suggested to play the role as inhibitors although the mechanism still is not clear. Also, as mentioned earlier serum and albumin can delay and/or inhibit nucleation and growth.

Bone Gla protein and osteonectin, but not the $\mathrm{Ca}^{2+}$ binding proteins calmodulin and parvalbumin, inhibit in vitro growth of hydroxylapatite. ${ }^{50,100}$ It was suggested that the conformation for binding to apatite was not favorable for the latter two proteins. Thus, $\mathrm{Ca}^{2+}$ binding by itself may not always be a good marker for which proteins control apatite formation. Notably, negatively charged amino acid motifs are important in both ectopic and topical mineralization.

\section{Adsorbed versus dissolved}

Experimental models with either dissolved or adsorbed proteins have been used to elucidate if certain proteins act as inhibitors or promoters of mineralization. In many cases proteins that act as inhibitors of apatite nucleation and growth when dissolved also act as promoter of mineralization when adsorbed. ${ }^{16,22,85,98,105-113}$ But for the case of bone and dentin most of the matrix proteins are not in solution. ${ }^{34,114}$ It has been suggested that a difference in conformation for proteins as dissolved and adsorbed can account for some of the observed differences in behavior with regard to apatite formation..$^{50}$ Preadsorption of proteins could lead to induction of mineralization if the mineralization-modulating proteins are in an appropriate conformation. Further, some proteins probably can bind to already formed mineral nuclei and thus stabilize them for further growth, ${ }^{16}$ inhibit dissolution, ${ }^{115}$ or inhibit further growth. ${ }^{104}$

The adsorbed proteins may in different ways affect mineralization caused by the change in interfacial energy after the protein adsorption. It has been suggested that proteins when adsorbed on any surface can promote nucleation, but when adsorbed on already formed crystals they may decrease further crystal growth. ${ }^{96,105}$ It has also been suggested that nonspecific protein adsorption decreases the substrateliquid surface tension and thus lower the nucleation ability of 
the substrate surface ${ }^{9}$ but might mostly be an effect on noninducing proteins covering the surface.

\section{Concentration of protein}

Along the in vivo timeline of mineralization, the presence of proteins will change also their concentration. Proteininduced mineral nucleation in solution decreases the amount of free ions and thus can drive the solution below (super) saturation and thus affect the ability of already started apatite formation to grow further. In the same manner $\mathrm{Ca}^{2+}$ chelating proteins in solution will increase the dissolution of already formed apatite crystals. Although some proteins can bind calcium when dissolved, it is also possible that their adsorption on specific apatite faces will inhibit or direct apatite growth. ${ }^{116}$

Apatite mineralization in vitro is increasingly inhibited with an increasing concentration of serum solution, most likely because the adsorbed proteins block further growth ${ }^{117-119}$ but can also lead to differences in morphology of crystal coatings after mineral growth on a variety of calcium phosphates. ${ }^{120}$ Human serum albumin has been pointed out as an important factor in this process, ${ }^{118}$ but also the biopolymers that bind to different sites on apatite are more effective together at inhibiting apatite growth. ${ }^{121}$ The effect of proteins on apatite growth and transformation depends not only on the proteins but also on the seed crystals. Overall, serum proteins are assumed to impede de novo formation of apatite but may not always hinder seeded growth. ${ }^{122}$

For many mineralization-related proteins, it has been found that they induce growth when dissolved in small amounts, but at a certain point they start to inhibit further growth of hydroxylapatite. ${ }^{27,63,84,123,124}$ Each of these in vitro effects has been attributed to interactions between the protein and specific faces of apatite. Combes and Rey have proposed that at low protein concentrations nucleation and growth are not much inhibited, but at higher concentrations adsorbed protein will inhibit growth (rather than nucleation) to such an extent that the overall mineral formation is inhibited. ${ }^{9}$

\section{Proteins and Polypeptides in Making Mineralized Constructs}

There is a very extensive body of research aimed at making use of oligo- or polypeptides for modulating cell attachment and growth, but so far the specific use of (poly)peptides aimed at acellular induction and modulation of apatite formation for use in bone tissue engineering applications is more sparse. In the following sections, we will highlight and comment on some more recent results from the use of proteins and peptides for making mineralized biomaterials and biomaterials that promote (acellular) mineralization.

\section{Blends of Mineral and Proteins}

There is a vast body of research on mixing proteins or peptides with apatite particles to make mineralized biomaterials. The aim is not necessarily to impose properties on the apatite particles themselves but rather to make composites in which apatite particles are immersed in an organic matrix, often in an attempt to mimic bone matrices, but very often not aiming to use the ability of the polypeptides to induce or modulate mineralization.
The success of composites of fibrin sealant and ceramic in vivo has been reported to be ambiguous, but in some cases they were able to induce the formation of woven bone. ${ }^{153}$ Because the bone remodeling will transform the woven bone into lamellar bone ${ }^{11}$ it might be of interest to aim at making scaffolds that at first induce formation of woven bone in vivo rather than lamellar bone.

There have been some studies of making collagen-mineral composites ${ }^{154-156}$ aimed at inducing bone repair. This type of matrix can readily be loaded with growth promoters for a wide variety of cells. This approach also benefits from the seeded growth in vivo that is less susceptible to interference from adsorbing proteins with regard to crystal growth. The main drawback is the nonautograft collagen with all the accompanying issues regarding disease transmission and immunorejection. The use of synthetic and biodegradable polymers that would provide a 3D network similar to that of collagen would hopefully circumvent those problems.

In a recent study of a collagen hydrogel aimed at soft tissue repair, it was suggested that calcium phosphate should be included ${ }^{157}$ because it has been suggested that $\mathrm{Ca}^{2+}$ ions are necessary for neurite growth. ${ }^{158}$ Thus such ions released from the scaffolds also would improve neurite healing. ${ }^{157}$ Indeed, a premineralized structure perhaps could also act as a reservoir of ions to promote mineralization. Also, it has earlier been suggested that because elevated ion concentrations are needed for apatite formation, dissolution of already formed or coated apatite will help to maintain the local ion concentrations at elevated levels. ${ }^{159}$

\section{Hydrogels}

A synthetic self-assembling oligopeptide (Ace-Gln-GlnArg-Phe-Glu-Trp-Glu-Phe-Glu-Gln-Gln-NH2) that forms $\beta$ sheet fibrils has been shown to promote healing of dental lesions. Two potential nonexclusive mechanisms were proposed; the peptides form a gel that acts as $\mathrm{Ca}$ ion chelator and/or it acts to inhibit apatite dissolution in the acidic oral environment. ${ }^{160}$ This study points to the possibility of repairing small defects in mineralized tissues with a gel structure that itself is not initially mineralized. To some extent this has already been achieved without polypeptide gels when the damaged section of bone has been delimited by a membrane barrier, ${ }^{161,162}$ but gelatin foams might impede healing by obstructing bone marrow growth ${ }^{163}$ although the authors comment on the possible use of bone inductive components to overcome this problem for large (even critical sized) bone defects.

The hydrophobic and basic P15 sequence (GTPGPQGIA GQRGVV) from collagen has been shown to bind to apatite particles. P15-coated apatite particles better induce bone formation when immersed in hydrogels and injected in vivo than just the apatite. ${ }^{164,165}$ This again stresses the usefulness of (synthetic) oligopeptides, but also when load bearing is not an immediate essential requirement that injectable hydrogel/ apatite composites could have a positive effect on bone formation.

\section{Polypeptide Coatings}

There are some approaches to drug delivery that make use of calcium phosphates; the drug is either present during the mineral preparation ${ }^{166,167}$ or later adsorbed onto the 
mineral ${ }^{168-170}$ and also bone morphogenetic protein (BMPs). ${ }^{171}$ One would expect that the former approach will enable a higher load and also a prolonged release. One could possibly alter the release kinetics by adding polypeptides to the outer surface of the apatite particles to make the mineral degrade slower or with a delayed onset of dissolution. This shows that the mineral phase of tissue engineering constructs also could be used as drug delivery devices. One study showed prolonged drug release by coating the mineral particles with albumin, ${ }^{170}$ but it is not clear if it is due to prolonged release of the adsorbed protein or because the mineral is degraded slower, although it has been shown that proteins adsorbed to apatites will delay their dissolution. ${ }^{103,115}$

Electrodeposition of amelogenin promotes ordered apatite mineralization in vitro and has been suggested as a way to produce mineralized constructs. ${ }^{172}$ Perhaps it would be interesting if this approach could be translated in vivo, that is, for repair of decayed enamel by using a chimeric approach with one end binding to the existing enamel and the other inducing enamel repair.

Further, as noted in a recent review, phosphorylation of synthetic polymers could be a way to mimic phosphorylated proteins in how they promote mineralization. ${ }^{173}$ This would avoid much of the problems associated with allogenic proteins whilst being applicable to a wide variety of polymers. Although one would again expect that conformation is an important issue to assure proper mineralization.

\section{Proteins Coprecipitated with Mineral}

As noted above there is a difference between coating an apatite and having the organic phase incorporated during the fabrication of the apatite itself, either as particles or coating on devices. By having polypeptides or proteins present during mineralization in vitro, it is possible to affect the morphology of the formed apatite. ${ }^{174-177}$ In many cases this type of incorporation of proteins or peptides into an apatite matrix will make the apatite less crystalline and thus also more susceptible to degradation by dissolution, although the mechanical strength could be improved by incorporating proteins. ${ }^{177}$ Apatite in bone is more easily dissolved than synthetic hydroxylapatite. ${ }^{7,178,179}$ Perhaps this is an desired starting point because the aim is to have the mineralized scaffolds being subjected to bone remodeling, which includes resorption of the initial apatite. ${ }^{180}$ To some extent this has been achieved by a matrix of collagen and apatite nanoparticles that was shown to induce processes of bone degradation and formation that is similar of bone remodeling $176,181,182$ although the formed bone was not hierarchical.

By adding a phosphoprotein to collagen, one can induce apatite formation in vitro, ${ }^{183}$ but because of the nonautograftrelated problems, it might be better to aim for recombinant collagen. ${ }^{83}$ However, the incorporated protein could improve the mineral phase by conveying a function such as improvement of degradation kinetics of the polymer substrate ${ }^{174,175}$ or adherence or stimulation of bone forming cells ${ }^{184,185}$ (see also above paragraphs on drug delivery in the Peptide Coatings section).

Even much simpler molecules such as peptides and polypeptides have been used to form apatitic constructs. Coprecipitation with monomeric peptides has been shown to have potential to make apatite nanoparticles that in turn can be mixed with dextran sulfate to make 3D sponges. Aspartic acid was shown to be more successful than both arginine and lysine in making the sponge and getting the best cellular response to the hybrid although the scaffold was deemed too weak to be suitable for load-bearing applications. ${ }^{186}$

Acidic peptides have been combined with hydrophobic groups (peptides or alkyls) to produce self-assembled nanofibers to be used for inducing mineralization, ${ }^{187-189}$ perhaps as a new class of injectable systems ${ }^{69}$ that perhaps are better suited for small rather than critical-size defects. ${ }^{190}$ Nanofibers made with amphiphiles with alkyl groups in the hydrophobic tail and serine or phosphoserine near the hydrophilic terminal gave amorphous deposits and apatite, respectively. ${ }^{189}$ Notably, in the latter case the crystals were oriented along the fibers. A similar system with phosphoserine promoted apatitic mineralization when coated on titanium. ${ }^{191}$ Amphiphiles with only peptides with aspartic acid in the hydrophilic tail that also forms nanotubular fiber meshes ${ }^{192}$ could probably also act as an organic matrix for mineralization. ${ }^{193}$

\section{Chimeric Peptides}

Some effort has been made to make protein or oligopeptide coatings on either apatite particles or apatite coatings to enhance cell response. Synthetic polypeptides that use specific functionalities from more than one parent protein could be used in tissue engineering applications for inducing bone formation. ${ }^{194}$ For example, one part binds to already formed apatite and the second is used as a cell-binding ligand. Indeed, many of the apatite-binding proteins also have domains with an arginine-glycine-aspartic acid (RGD) or other cell-binding ligands. ${ }^{194}$ It has been suggested that by combining apatitenucleating domains from one protein and cell-binding domain from another, one can induce desired function in biomedical applications. ${ }^{126}$ The apatite-binding domain from pig bone sialoprotein was combined with the collagen-binding site of decorin into a chimeric protein. This chimer was bound to collagen and was found to induce apatite formation. ${ }^{126}$ Gilbert et al. used a similar approach using the N15 terminal from statherin and an RGD containing hexapeptide from osteopontin, ${ }^{195}$ which mediated a dose-dependent adhesion of melanoma cells but not without the hexapeptide. An even more downscaled approach is to attach an RGD sequence to a septa-glutamic acid. ${ }^{196}$ The glutamic acid residue bound to the apatite, and the RGD sequence attracted mesenchymal stem cells more effectively than the RGD without the septa-Glu. A recent study has cast a doubt on this type of approach because it was claimed that since apatite is so prone to protein adsorption, any preattached cell ligands will be covered by an array of blood proteins, ${ }^{197}$ although the approach still could be useful to improve cell seeding prior to implantation.

There already are chimeric proteins in the body because many of the bone matrix proteins bind to collagen and have sites for apatite formation or osteoblast attachment-for example, osteonectin ${ }^{49}$ and bone sialoprotein. ${ }^{198,199}$ The use of synthetic chimeric polypeptides could very well be a way to avoid the xeno/allograft-related problems while tailoring specific polypeptides for tissue engineering approaches. In the case of bone tissue engineering, the chimeric approach might be useful for coating or loading of ex vivo formed apatite constructs. 


\section{Concluding Remarks}

The remaining crux is to determine if protein-apatite (coated) scaffolds can have a positive effect on apatite formation in vivo under the interference from blood proteins and surrounding tissue, and ultimately lead to new bone formation and remodeling in the implantation site. The polymeric scaffold that is intended as a template for apatite formation does not necessarily have to fulfill the ratios of mineral-toorganic phase of mature bone because the aim of tissue engineering is to create a starting point for the human body so that remodeling or healing is promoted. Ideally, the polymeric peptide (coated) scaffold should also be tailored for angiogenesis and a host of other characteristics.

Proteins are natural and necessary components of the mineralization of bone apatite in vivo. Taking the step of using (synthetic) proteins or protein fragments to induce apatite formation is thus very appealing. Such elements could be used in the preparation of scaffolds for enhancing the apatite mineralization process that leads to bone formation.

Because there are so many proteins that affect the mechanical, biochemical, and physicochemical properties of the formed apatite, by using proteins or well-designed fragments it should be possible to

- induce nucleation,

- induce and modulate growth,

- incorporate polypeptides or proteins during apatite growth that yield properties that can induce bone remodeling and vascularization, and

- coat the apatite with polypeptides that induce appropriate cell attachment and remodeling, and modulation of mineral dissolution.

The idea is thus to make use of a combination of strategies to achieve a good starting point for the bodily responses to take over so that the engineered scaffold can be transformed into mature bone.

For the future we already now see an increasing trend in borrowing traits from various mineralization-related proteins (rather than the whole protein) and applying them for tailored mineralization on scaffolds that should lead to mineral phase for its intended function or for such that mineralization is better avoided. One would perhaps also expect more computer modeling of existing apatite-binding domains to determine more completely how proteins interact with apatite surface and ions in solution, and compare those findings with structural matching between apatite and novel oligopeptides. Current trends and advances in oligo- and polypeptide design and synthesis promise a very high degree of control of end product that in the end could be useful in improving the mineralization characteristics of emerging multifunctional bone tissue engineering scaffolds.

\section{Acknowledgments}

J. Benesch wishes to acknowledge the financial support from FCT, postdoctoral fellowship scholarship SFRH/BPD/ $17584 / 2004$. This work was carried out under the scope of the European Union NoE EXPERTISSUES (NMP3-CT-2004500283) and partially funded by the European Union FP6 STREP Project HIPPOCRATES (NMP3-CT-2003-505758) and FCT project ProteoLight (PTDC/FIS/68517/2006).

\section{Disclosure Statement}

No competing financial interests exist.

\section{References}

1. Vaccaro, A.R. The role of the osteoconductive scaffold in synthetic bone graft. Orthopedics 25, S571, 2002.

2. White, C., Gardiner, E., and Eisman, J. Tissue specific and vitamin D responsive gene expression in bone. Mol Biol Rep 25, 45, 1998.

3. van Blitterswijk, C., Grote, J., Kuijpers, W., Daems, W., and de Groot, K. Macropore tissue ingrowth: a quantitative and qualitative study on hydroxyapatite ceramic. Biomaterials 7, 137, 1986

4. Kim, H.-M., Himeno, T., Kawashita, M., Kokubo, T., and Nakamura, T. The mechanism of biomineralization of bonelike apatite on synthetic hydroxyapatite: an in vitro assessment. J R Soc Interface 1, 17, 2004.

5. Oliveira, A.L., Mano, J.F., and Reis, R.L. Nature-inspired calcium phosphate coatings: present status and novel advances in the science of mimicry. Curr Op Solid State Mater Sci 7, 309, 2003.

6. Fujibayashi, S., Neo, M., Kim, H.-M., Kokubo, T., and Nakamura, T. A comparative study between in vivo bone ingrowth and in vitro apatite formation on $\mathrm{Na} 2 \mathrm{O}-\mathrm{CaO}-\mathrm{SiO} 2$ glasses. Biomaterials 24, 1349, 2003.

7. Ducheyne, P., and Qiu, Q. Bioactive ceramics: the effect of surface reactivity on bone formation and bone cell function. Biomaterials 20, 2287, 1999.

8. Davies, J.E. Bone bonding at natural and biomaterial surfaces. Biomaterials 28, 5058, 2007.

9. Combes, C., and Rey, C. Adsorption of proteins and calcium phosphate materials bioactivity. Biomaterials 23, 2817, 2002.

10. Glimcher, M.J. Bone: nature of the calcium phosphate crystals and cellular, structural, and physical chemical mechanisms in their formation. In: Medical Mineraology and Geochemistry, 2006, pp. 223-282.

11. Buckwalter, J.A., Glimcher, M.J., Cooper, R.R., and Recker, R. Bone biology. 1. Structure, blood-supply, cells, matrix, and mineralization. J Bone Joint Surg Am 77A, 1256, 1995.

12. Salgado, A.J., Coutinho, O.P., and Reis, R.L. Bone tissue engineering: state of the art and future trends. Macromol Biosci 4, 743, 2004.

13. Robling, A.G., Castillo, A.B., and Turner, C.H. Biomechanical and molecular regulation of bone remodeling. Annu Rev Biomed Eng 8, 455, 2006.

14. Ai-Aql, Z.S., Alagl, A.S., Graves, D.T., Gerstenfeld, L.C., and Einhorn, T.A. Molecular mechanisms controlling bone formation during fracture healing and distraction osteogenesis. J Dent Res 87, 107, 2008.

15. Wopenka, B., and Pasteris, J.D. A mineralogical perspective on the apatite in bone. Mater Sci Eng C 25, 131, 2005.

16. Boskey, A. Bone and cartilage mineralization. In: Brighton, C.T., Friedlaender, G., and Lane, J.M., eds. Bone Formation and Repair. : American Academy of Orthopaedic Surgeons, 1994, pp. 23-38.

17. Cho, G.Y., Wu, Y.T., and Ackerman, J.L. Detection of hydroxyl ions in bone mineral by solid-state NMR spectroscopy. Science 300, 1123, 2003.

18. Taylor, M.G., Parker, S.F., Simkiss, K., and Mitchell, P.C.H. Bone mineral: evidence for hydroxy groups by inelastic neutron scattering. Phys Chem Chem Phys 3, 1514, 2001. 
19. Pasteris, J.D., Wopenka, B., Freeman, J.J., Rogers, K., Valsami-Jones, E., van der Houwen, J.A.M., and Silva, M.J. Lack of $\mathrm{OH}$ in nanocrystalline apatite as a function of degree of atomic order: implications for bone and biomaterials. Biomaterials 25, 229, 2004.

20. Gorski, J.P. Is all bone the same? Distinctive distributions and properties of non-collagenous matrix proteins in lamellar vs. woven bone imply the existence of different underlying osteogenic mechanisms. Crit Rev Oral Biol Med 9, 201, 1998.

21. Gehron, R.P. Normal bone formation: structure. In: Brighton, C.T., Friedlaender, G., and Lane, J.M., eds. Bone Formation and Repair. : American Academy of Orthopaedic Surgeons, 1994, pp. 3-12.

22. Boskey, A.L. Matrix proteins and mineralization: an overview. Connect Tissue Res 35, 411, 1996.

23. Sarig, S. Aspartic acid nucleates the apatite crystallites of bone: a hypothesis. Bone 35, 108, 2004.

24. Veis, A. Mineralization in organic matrix frameworks. In: Dove, P.M., de Yoreo, J.J., and Weiner, S., eds. Biomineralization. : Mineralogical Society of America, 2003, pp. 249-289.

25. Gorski, J.P. Acidic phosphoproteins from bone-matrix-a structural rationalization of their role in biomineralization. Calcif Tissue Int 50, 391, 1992.

26. Weiner, S., and Wagner, H.D. The material bone: structure mechanical function relations. Annu Rev Mater Sci 28, 271, 1998.

27. Hunter, G.K., Hauschka, P.V., Poole, A.R., Rosenberg, L.C., and Goldberg, H.A. Nucleation and inhibition of hydroxyapatite formation by mineralized tissue proteins. Biochem J 317, 59, 1996.

28. Boskey, A.L. Biomineralization: an overview. Connect Tissue Res 44, 5, 2003.

29. Kresse, H. Proteoglycans-structure and functions. In: Gabius, H.-J., and Gabius, S., eds. Glycosciences: Status and Perspectives. Weinheim: Chapman \& Hall GmbH, 1997, pp. 201-222.

30. Veis, A. Biomineralization: on the trail of the phosphate. Part II: phosphophoryn, the DMPs, and more. J Dent Res 83, 6, 2004.

31. Veis, A. Biomineralization: on the trail of the phosphate. Part I: chance encounters and the path to dentin. J Dent Res 82, 941, 2003.

32. Butler, W.T., and Ritchie, H. The nature and functionalsignificance of dentin extracellular-matrix proteins. Int J Dev Biol 39, 169, 1995.

33. Embery, G., Hall, R., Waddington, R., Septier, D., and Goldberg, M. Proteoglycans in dentinogenesis. Crit Rev Oral Biol Med 12, 331, 2001.

34. Termine, J.D. Bone and tooth mineralization: matrix effects and crystal development. Prog Cryst Growth Char 3, 65, 1980.

35. Margolis, H.C., Beniash, E., and Fowler, C.E. Role of macromolecular assembly of enamel matrix proteins in enamel formation. J Dent Res 85, 775, 2006.

36. Roach, H.I. Why does bone matrix contain non-collagenous proteins? The possible roles of osteocalcin, osteonectin, osteopontin and bone sialoprotein in bone mineralisation and resorption. Cell Biol Int 18, 617, 1994.

37. Qin, C., D'Souza, R., and Feng, J.Q. Dentin matrix protein 1 (DMP1): new and important roles for biomineralization and phosphate homeostasis. J Dent Res 86, 1134, 2007.

38. Veis, A., and Perry, A. The phosphoprotein of the dentin matrix. Biochemistry 6, 2409, 1967.
39. Lee, S.L., Veis, A., and Glonek, T. Dentin phosphoproteinextracellular calcium-binding protein. Biochemistry 16, 2971, 1977.

40. He, G., Ramachandran, A., Dahl, T., George, S., Schultz, D., Cookson, D., Veis, A., and George, A. Phosphorylation of phosphophoryn is crucial for its function as a mediator of biomineralization. J Biol Chem 280, 33109, 2005.

41. Alini, M., Matsui, Y., Dodge, G.R., and Poole, A.R. The extracellular-matrix of cartilage in the growth plate before and during calcification-changes in composition and degradation of type-II collagen. Calcif Tissue Int 50, 327, 1992.

42. Luo, G., Ducy, P., McKee, M., Pinero, G., Loyer, E., Behringer, R., and Karsenty, G. Spontaneous calcification of arteries and cartilage in mice lacking matrix GLA protein. Nature 386, 78, 1997.

43. Melrose, J., Smith, S., Cake, M., Read, R., and Whitelock, J. Perlecan displays variable spatial and temporal immunolocalisation patterns in the articular and growth plate cartilages of the ovine stifle joint. Histochem Cell Biol 123, 561, 2005.

44. Orsini, G., Ruggeri, A., Mazzoni, A., Papa, V., Mazzotti, G., Di Lenarda, R., and Breschi, L. Immunohistochemical identification of decorin and biglycan in human dentin: a correlative field emission scanning electron microscopy/ transmission electron microscopy study. Calcif Tissue Int 81, 39, 2007.

45. Yao, K.L., Todescan, R., and Sodek, J. Temporal changes in matrix protein-synthesis and messenger-Rna expression during mineralized tissue formation by adult-rat bonemarrow cells in culture. I Bone Miner Res 9, 231, 1994.

46. Sugars, R.V., Milan, A.A., Brown, J.O., Waddington, R.J., Hall, R.C., and Embery, G. Molecular interaction of recombinant decorin and biglycan with type I collagen influences crystal growth. Connect Tissue Res 44, 189, 2003.

47. Oppenheim, F., Hay, D.I., and Franzbla, C. Proline-rich proteins from human parotid saliva 1 isolation and partial characterization. Biochemistry 10, 4233, 1971.

48. Raj, P.A., Johnsson, M., Levine, M.J., and Nancollas, G.H. Salivary statherin-dependence on sequence, charge, hydrogen-bonding potency, and helical conformation for adsorption to hydroxyapatite and inhibition of mineralization. J Biol Chem 267, 5968, 1992.

49. Termine, J.D., Belcourt, A.B., Conn, K.M., and Kleinman, H.K. Mineral and collagen-binding proteins of fetal calf bone. J Biol Chem 256, 10403, 1981.

50. Romberg, R.W., Werness, P.G., Riggs, B.L., and Mann, K.G. Inhibition of hydroxyapatite crystal-growth by bonespecific and other calcium-binding proteins. Biochemistry 25, 1176, 1986.

51. Weiner, S., and Traub, W. Organization of hydroxyapatite crystals within collagen fibrils. FEBS Lett 206, 262, 1986.

52. Rosengren, A., Pavlovic, E., Oscarsson, S., Krajewski, A., Ravaglioli, A., and Piancastelli, A. Plasma protein adsorption pattern on characterized ceramic biomaterials. Biomaterials 23, 1237, 2002.

53. Tiselius, A., Hjerten, S., and Levin, O. Protein chromatography on calcium phosphate columns. Arch Biochem Biophys 65, 132, 1956.

54. Gorbunoff, M.J. The interaction of proteins with hydroxyapatite. 1. Role of protein charge and structure. Anal Biochem 136, 425, 1984.

55. Gorbunoff, M.J. The interaction of proteins with hydroxyapatite. 2. Role of acidic and basic groups. Anal Biochem 136, 433, 1984. 
56. Price, P.A., Otsuka, A.S., Poser, J.W., Kristaponis, J., and Raman, N. Characterization of a gamma-carboxyglutamic acid-containing protein from bone. Proc Natl Acad Sci USA $73,1447,1976$.

57. Hoang, Q.Q., Sicheri, F., Howard, A.J., and Yang, D.S.C. Bone recognition mechanism of porcine osteocalcin from crystal structure. Nature 425, 977, 2003.

58. Capriotti, L.A., Beebe, T.P., and Schneider, J.P. Hydroxyapatite surface-induced peptide folding. J Am Chem Soc 129, 5281, 2007.

59. Richardson, C.F., Johnsson, M., Raj, P.A., Levine, M.J., and Nancollas, G.H. The influence of histatin- 5 fragments on the mineralization of hydroxyapatite. Arch Oral Biol 38, 997, 1993.

60. Ohta, K., Monma, H., Tanaka, J., and Eda, H. Interaction between hydroxyapatite and proteins by liquid chromatography using simulated body fluids as eluents. J Mater Sci Mater Med 13, 633, 2002.

61. George, A., Bannon, L., Sabsay, B., Dillon, J.W., Malone, J., Veis, A., Jenkins, N.A., Gilbert, D.J., and Copeland, N.G. The carboxyl-terminal comain of phosphophoryn contains unique extended triplet amino acid repeat sequences forming ordered carboxyl-phosphate interaction ridges that may be essential in the biomineralization process. J Biol Chem 271, 32869, 1996.

62. Fujisawa, R., Wada, Y., Nodasaka, Y., and Kuboki, Y. Acidic amino acid-rich sequences as binding sites of osteonectin to hydroxyapatite crystals. Biochem Biophys Acta 1292, 53, 1996.

63. Stubbs, J.T., Mintz, K.P., Eanes, E.D., Torchia, D.A., and Fisher, L.W. Characterization of native and recombinant bone sialoprotein: delineation of the mineral-binding and cell adhesion domains and structural analysis of the RGD domain. J Bone Miner Res 12, 1210, 1997.

64. Hay, D.I. Interaction of human parotid salivary proteins with hydroxyapatite. Arch Oral Biol 18, 1517, 1973.

65. Fujisawa, R., and Kuboki, Y. Preferential adsorption of dentin and bone acidic proteins on the (100) face of hydroxyapatite crystals. Biochem Biophys Acta 1075, 56, 1991.

66. Garcia-Ramos, J.V., and Carmona, P. The effect of some homopolymers on the crystallization of calcium phosphates. J Cryst Growth 57, 336, 1982.

67. Dahlin, S., Angstrom, J., and Linde, A. Dentin phosphoprotein sequence motifs and molecular modeling: conformational adaptations to mineral crystals. Eur J Oral Sci 106, 239, 1998.

68. Huq, N.L., Cross, K.J., and Reynolds, E.C. Molecular modelling of a multiphosphorylated sequence motif bound to hydroxyapatite surfaces. J Mol Model 6, 35, 2000.

69. Firth, A., Aggeli, A., Burke, J.L., Yang, X.B., and Kirkham, J. Biomimetic self-assembling peptides as injectable scaffolds for hard tissue engineering. Nanomedicine 1, 189, 2006.

70. Kirkham, J., Brookes, S.J., Shore, R.C., Wood, S.R., Smith, D.A., Zhang, J., Chen, H.F., and Robinson, C. Physicochemical properties of crystal surfaces in matrix-mineral interactions during mammalian biomineralisation. Curr Opin Colloid Interface Sci 7, 124, 2002.

71. Stupp, S.I., and Braun, P.V. Molecular manipulation of microstructures: biomaterials, ceramics, and semiconductors. Science 277, 1242, 1997.

72. Sikiric, M.D., and Furedi-Milhofer, H. The influence of surface active molecules on the crystallization of biominerals in solution. Adv Colloid Interface Sci 128, 135, 2006.
73. He, G., Dahl, T., Veis, A., and George, A. Nucleation of apatite crystals in vitro by self-assembled dentin matrix protein, 1. Nature Mater 2, 552, 2003.

74. Steinberg, A.D., Willey, R., and Drummond, J.L. In vivo comparisons of clot formation on titanium and hydroxyapatitecoated titanium. J Periodontol 63, 990, 1992.

75. Kikuchi, L., Park, J.Y., Victor, C., and Davies, J.E. Platelet interactions with calcium-phosphate-coated surfaces. Biomaterials 26, 5285, 2005.

76. Hasselbacher, P. C3-activation by monosodium urate monohydrate and other crystalline material. Arthritis Rheum 22, 571, 1979.

77. Klein, C., Degroot, K., Vermeiden, J.P.W., and Vankamp, G. Interaction of some serum-proteins with hydroxylapatite and other materials. J Biomed Mater Res 14, 705, 1980.

78. Hong, J., Andersson, J., Ekdahl, K.N., Elgue, G., Axen, N., Larsson, R., and Nilsson, B. Titanium is a highly thrombogenic biomaterial: possible implications for osteogenesis. Thromb Haemost 82, 58, 1999.

79. Pramatarova, L., Pecheva, E., Presker, R., Pham, M.T., Maitz, M.F., and Stutzmann, M. Hydroxyapatite growth induced by native extracellular matrix deposition on solid surfaces. Eur Cell Mater 9, 9, 2005.

80. Boskey, A.L. Biomineralization: conflicts, challenges, and opportunities. J Cell Biochem 83, 1998.

81. Howell, D.S., Pita, J.C., Marquez, J.F., and Gatter, R.A. Demonstration of macromolecular inhibitor(s) of calcification and nucleational factor(s) in fluid from calcifying sites in cartilage. J Clin Invest 48, 630, 1969.

82. Weiner, S., and Addadi, L. Design strategies in mineralized biological materials. J Mater Chem 7, 689, 1997.

83. Zhai, Y., Cui, F.Z., and Wang, Y. Formation of nanohydroxyapatite on recombinant human-like collagen fibrils. Curr Appl Phys 5, 429, 2005.

84. Boskey, A., Spevak, L., Tan, M., Doty, S.B., and Butler, W.T. Dentin sialoprotein (DSP) has limited effects on in vitro apatite formation and growth. Calcif Tissue Int 67, 472, 2000.

85. Hunter, G.K., and Goldberg, H.A. Nucleation of hydroxyapatite by bone sialoprotein. Proc Natl Acad Sci USA 90, 8562, 1993.

86. Harris, N.L., Rattray, K.R., Tye, C.E., Underhill, T.M., Somerman, M.J., D'Errico, J.A., Chambers, A.F., Hunter, G.K., and Goldberg, H.A. Functional analysis of bone sialoprotein: identification of the hydroxyapatite-nucleating and cell-binding domains by recombinant peptide expression and site-directed mutagenesis. Bone 27, 795, 2000.

87. Rammelt, S., Neumann, M., Hanisch, U., Reinstorf, A., Pompe, W., Zwipp, H., and Biewener, A. Osteocalcin enhances bone remodeling around hydroxyapatite/collagen composites. J Biomed Mater Res 73A, 284, 2005.

88. Chenu, C., Colucci, S., Grano, M., Zigrino, P., Barattolo, R., Zambonin, G., Baldini, N., Vergnaud, P., Delmas, P.D., and Zallone, A.Z. Osteocalcin induces chemotaxis, secretion of matrix proteins, and calcium-mediated intracellular signaling in human osteoclast-like cells. J Cell Biol 127, 1149, 1994.

89. Krout, A., Wen, H.B., Hippensteel, E., and Li, P.J. A hybrid coating of biomimetic apatite and osteocalcin. J Biomed Mater Res A 73A, 377, 2005.

90. He, G., Dahl, T., Veis, A., and George, A. Dentin matrix protein 1 initiates hydroxyapatite formation in vitro. Connect Tissue Res 44, 240, 2003.

91. He, G., Gajjeraman, S., Schultz, D., Cookson, D., Qin, C.L., Butler, W.T., Hao, J.J., and George, A. Spatially and 
temporally controlled biomineralization is facilitated by interaction between self-assembled dentin matrix protein 1 and calcium phosphate nuclei in solution. Biochemistry 44, 16140, 2005.

92. Furedimilhofer, H., Moradianoldak, J., Weiner, S., Veis, A., Mintz, K.P., and Addadi, L. Interactions of matrix proteins from mineralized tissues with octacalcium phosphate. Connect Tissue Res 30, 251, 1994.

93. Wu, Y., Ackerman, J.L., Strawich, E.S., Rey, C., Kim, H.M., and Glimcher, M.J. Phosphate ions in bone: identification of a calcium-organic phosphate complex by P-31 solid-state NMR spectroscopy at early stages of mineralization. Calcif Tissue Int 72, 610, 2003.

94. Stetler-Stevenson, W.G., and Veis, A. Type-I collagen shows a specific binding-affinity for bovine dentin phosphophoryn. Calcif Tissue Int 38, 135, 1986.

95. Glimcher, M.J. Recent studies of the mineral phase in bone and its possible linkage to the organic matrix by proteinbound phosphate bonds. Philos Trans R Soc Lond B Biol Sci 304, 479, 1984.

96. Rohanizadeh, R., Padrines, M., Bouler, J., Couchourel, D., Fortun, Y., and Daculsi, G. Apatite precipitation after incubation of biphasic calcium-phosphate ceramic in various solutions: influence of seed species and proteins. J Biomed Mater Res 42, 530, 1998.

97. Serro, A.P., Bastos, M., Pessoa, J.C., and Saramago, B. Bovine serum albumin conformational changes upon adsorption on titania and on hydroxyapatite and their relation with biomineralization. J Biomed Mater Res A 70A, 420, 2004.

98. Tsortos, A., Ohki, S., Zieba, A., Baier, R.E., and Nancollas, G.H. The dual role of fibrinogen as inhibitor and nucleator of calcium phosphate phases: the importance of structure. J Colloid Interface Sci 177, 257, 1996.

99. Takeuchi, A., Ohtsuki, C., Miyazaki, T., Kamitakahara, M., Ogata, S.-i., Yamazaki M, Furutani Y, Kinoshita H, and Tanihara M. Heterogeneous nucleation of hydroxyapatite on protein: structural effect of silk sericin. J R Soc Interface 2, 373, 2005.

100. Murshed, M., Schinke, T., McKee, M.D., and Karsenty, G. Extracellular matrix mineralization is regulated locally; different roles of two gla-containing proteins. J Cell Biol 165, 625, 2004.

101. Steitz, S.A., Speer, M.Y., McKee, M.D., Liaw, L., Almeida, M., Yang, H., and Giachelli, C.M. Osteopontin inhibits mineral deposition and promotes regression of ectopic calcification. Am J Pathol 161, 2035, 2002.

102. Wada, T., McKee, M.D., Steitz, S., and Giachelli, C.M. Calcification of vascular smooth muscle cell cultures inhibition by osteopontin. Circ Res 84, 166, 1999.

103. Wikiel, K., Burke, E.M., Perich, J.W., Reynolds, E.C., and Nancollas, G.H. Hydroxyapatite mineralization and demineralization in the presence of synthetic phosphorylated pentapeptides. Arch Oral Biol 39, 715, 1994.

104. Shaw, W.J., Long, J.R., Campbell, A.A., Stayton, P.S., and Drobny, G.P. A solid state NMR study of dynamics in a hydrated salivary peptide adsorbed to hydroxyapatite. J Am Chem Soc 122, 7118, 2000.

105. Addadi, L., and Weiner, S. Interactions between acidic proteins and crystals: stereochemical requirements in biomineralization. Proc Natl Acad Sci USA 82, 4110, 1985.

106. Chen, C.C., Boskey, A.L., and Rosenberg, L.C. The inhibitory effect of cartilage proteoglycans on hydroxyapatite growth. Calcif Tissue Int 36, 285, 1984.
107. Chen, C.C., and Boskey, A.L. The effects of proteoglycans from different cartilage types on in vitro hydroxyapatite proliferation. Calcif Tissue Int 39, 324, 1986.

108. Dorozhkina, E.I., and Dorozhkin, S.V. Application of the turbidity measurements to study in situ crystallization of calcium phosphates. Colloids Surf A Physicochem Eng Asp 203, 237, 2002.

109. Hunter, G.K., and Goldberg, H.A. Modulation of crystalformation by bone phosphoproteins-role of glutamic acidrich sequences in the nucleation of hydroxyapatite by bone sialoprotein. Biochem J 302, 175, 1994.

110. Linde, A., Lussi, A., and Crenshaw, M.A. Mineral induction by immobilized polyanionic proteins. Calcif Tissue Int 44, 286, 1989

111. Marques, P., Serro, A.P., Saramago, B.J., Fernandes, A.C., Magalhaes, M.C.F., and Correia, R.N. Mineralisation of two phosphate ceramics in HBSS: role of albumin. Biomaterials 24, 451, 2003.

112. Nancollas, G.H., Lore, M., Perez, L., Richardson, C., and Zawacki, S.J. Mineral phases of calcium phosphate. Anat Rec 224, 234, 1989.

113. Waddington, R.J., Roberts, H.C., Sugars, R.V., and Schönherr, E. Differential roles for small leucine-rich proteoglycans in bone formation. Eur Cell Mater 6, 12, 2003.

114. Kinne, R.W., and Fisher, L.W. Keratan sulfate proteoglycan in rabbit compact bone is bone sialoprotein II. J Biol Chem 262, 10206, 1987.

115. Chin, K.O.A., Johnsson, M., Bergey, E.J., Levine, M.J., and Nancollas, G.H. A constant composition kinetics study of the influence of salivary cystatins, statherin, amylase and human serum albumin on hydroxyapatite dissolution. Colloids Surf A Physicochem Eng Asp 78, 229, 1993.

116. Doi, Y., Okuda, R., Takezawa, Y., Shibata, S., Moriwaki, Y., Wakamatsu, N., Shimizu, N., Moriyama, K., and Shimokawa, H. Osteonectin inhibiting de novo formation of apatite in the presence of collagen. Calcif Tissue Int 44, 200, 1989.

117. Radin, S., Ducheyne, P., Rothman, B., and Conti, A. The effect of in vitro modeling conditions on the surface reactions of bioactive glass. J Biomed Mater Res 37A, 363, 1997.

118. Garnett, J., and Dieppe, P. The effects of serum and human albumin on calcium hydroxyapatite crystal growth. Biochem J 266, 863, 1990.

119. Wen, H.B., Hippensteel, E.A., and Li, P. Protein adsorption property of a biomimetic apatite coating. Key Eng Mater 284, 403, 2005.

120. Rzeszutek, K., Guo, L.H., and Davies, J.E. Importance of including proteins in experimental models aimed at studying reactive surface apatite layers on calcium phosphates. In: Bioceramics. 14, 97, 2002.

121. Rees, S.G., Wassell, D.T.H., Shellis, R.P., and Embery, G. Effect of serum albumin on glycosaminoglycan inhibition of hydroxyapatite formation. Biomaterials 25, 971, 2004.

122. Radin, S., and Ducheyne, P. Effect of serum proteins on solution-induced surface transformations of bioactive ceramics. J Biomed Mater Res 30, 273, 1996.

123. Boskey, A.L., Maresca, M., Doty, S., Sabsay, B., and Veis, A. Concentration-dependent effects of dentin phosphophoryn in the regulation of in vitro hydroxyapatite formation and growth. Bone Miner 11, 55, 1990.

124. Combes, C., Rey, C., and Freche, M. In vitro crystallization of octacalcium phosphate on type I collagen: influence of serum albumin. J Mater Sci Mater Med 10, 153, 1999. 
125. Zeng, H., Chittur, K.K., and Lacefield, W.R. Dissolution/ reprecipitation of calcium phosphate thin films produced by ion beam sputter deposition technique. Biomaterials 20, 443, 1999.

126. Hunter, G.K., Poitras, M.S., Underhill, T.M., Grynpas, M.D., and Goldberg, H.A. Induction of collagen mineralization by a bone sialoprotein-decorin chimeric protein. J Biomed Mater Res 55, 496, 2001.

127. Daculsi, G., Pilet, P., Cottrel, M., and Guicheux, G. Role of fibronectin during biological apatite crystal nucleation: ultrastructural characterization. J Biomed Mater Res 47, 228, 1999.

128. Wen, H.B., and Moradian-Oldak, J. Modification of calciumphosphate coatings on titanium by recombinant amelogenin. J Biomed Mater Res 64A, 483, 2003.

129. Nancollas, G.H., and Budz, J.A. Analysis of particle size distribution of hydroxyapatite crystallites in the presence of synthetic and natural polymers. J Dent Res 69, 1678, 1990.

130. Human Serum Albumin, Human Protein Reference Database, Acc Num NP_000468.1, Date accessed: 2007-06-05.

131. Beniash, E., Simmer, J.P., and Margolis, H.C. The effect of recombinant mouse amelogenins on the formation and organization of hydroxyapatite crystals in vitro. J Struct Biol 149, 182, 2005.

132. Moradian-Oldak, J., and Goldberg, M. Amelogenin supramolecular assembly in vitro compared with the architecture of the forming enamel matrix. Cells Tissues Organs 181, 202, 2005.

133. Boskey, A.L., Spevak, L., Doty, S.B., and Rosenberg, L. Effects of bone CS-proteoglycans, DS-decorin, and DSbiglycan on hydroxyapatite formation in a gelatin gel. Calcif Tissue Int 61, 298, 1997.

134. Embery, G., Rees, S., Hall, R., Rose, K., Waddington, R., and Shellis, P. Calcium- and hydroxyapatite-binding properties of glucuronic acid-rich and iduronic acid-rich glycosaminoglycans and proteoglycans. Eur J Oral Sci 106, 267, 1998.

135. Ameye, L., and Young, M.F. Mice deficient in small leucinerich proteoglycans: novel in vivo models for osteoporosis, osteoarthritis, Ehlers-Danlos syndrome, muscular dystrophy, and corneal diseases. Glycobiology 12, 107R, 2002.

136. Bianco, P., Fisher, L.W., Young, M.F., Termine, J.D., and Robey, P.G. Expression and localization of the two small proteoglycans biglycan and decorin in developing human skeletal and non-skeletal tissues. J Histochem Cytochem 38, $1549,1990$.

137. Corsi, A., Xu, T., Chen, X.D., Boyde, A., Liang, J., Mankani, M., Sommer, B., Iozzo, R.V., Eichstetter, I., Robey, P.G., Bianco, P., and Young, M.F. Phenotypic effects of biglycan deficiency are linked to collagen fibril abnormalities, are synergized by decorin deficiency, and mimic EhlersDanlos-like changes in bone and other connective tissues. J Bone Miner Res 17, 1180, 2002.

138. Rees, S.G., Shellis, R.P., and Embery, G. Inhibition of hydroxyapatite crystal growth by bone proteoglycans and proteoglycan components. Biochem Biophys Res Commun 292, 727, 2002.

139. Gorski, J.P., Wang, A., Lovitch, D., Law, D., Powell, K., and Midura, R.J. Extracellular bone acidic glycoprotein-75 defines condensed mesenchyme regions to be mineralized and localizes with bone sialoprotein during intramembranous bone formation. J Biol Chem 279, 25455, 2004.

140. Schinke, T., Amendt, C., Trindl, A., Poschke, O., MullerEsterl, W., and Jahnen-Dechent W. The serum protein
alpha(2)-HS glycoprotein/fetuin inhibits apatite formation in vitro and in mineralizing calvaria cells-a possible role in mineralization and calcium homeostasis. J Biol Chem 271, 20789, 1996.

141. Fetuin, Human Protein Reference Database, Acc Num NP_001613.1, Date accessed: 2007-06-05.

142. Fibronectin, Human Protein Reference Database, Acc Num NP_997647.1, Date accessed: 2007-06-05.

143. Wallin, R., Wajih, N., Greenwood, G.T., and Sane, D.C. Arterial calcification: a review of mechanisms, animal models, and the prospects for therapy. Med Res Rev 21, 274, 2001.

144. Hauschka, P.V., Lian, J.B., and Gallop, P.M. Direct identification of calcium-binding amino-acid, gammacarboxyglutamate, in mineralized tissue. Proc Natl Acad Sci USA 72, 3925, 1975.

145. Osteocalcin, Human Protein Reference Database, Acc Num NM_199173.2, Date accessed: 2007-06-05.

146. Pampena, D.A., Robertson, K.A., Litvinova, O., Lajoie, G., Goldberg, H.A., and Hunter, G.K. Inhibition of hydroxyapatite formation by osteopontin phosphopeptides. Biochem J 378, 1083, 2004.

147. McKee, M.D., and Nanci, A. Osteopontin at mineralized tissue interfaces in bone, teeth, and osseointegrated implants: ultrastructural distribution and implications for mineralized tissue formation, turnover, and repair. Microsc Res Tech 33, 141, 1996.

148. Sabsay, B., Stetlerstevenson, W.G., Lechner, J.H., and Veis, A. Domain-structure and sequence distribution in dentin phosphophoryn. Biochem J 276, 699, 1991.

149. Seiffert, D. Detection of vitronectin in mineralized bone matrix. J Histochem Cytochem 44, 275, 1996.

150. Vitronector Precursor, Human Protein Reference Database, Acc Num NM_000638.2, Date accessed: 2007-06-05.

151. Serro, A.P., Fernandes, A.C., Saramago, B., Lima, J., and Barbosa, M.A. Apatite deposition on titanium surfacesthe role of albumin adsorption. Biomaterials 18, 963, 1997.

152. Peri, S., Navarro, J.D., Amanchy, R., Kristiansen, T.Z., Jonnalagadda, C.K., Surendranath, V., Niranjan, V., Muthusamy, B., Gandhi, T.K.B., Gronborg, M., Ibarrola, N., Deshpande, N., Shanker, K., Shivashankar, H.N., Rashmi, B.P., Ramya, M.A., Zhao, Z.X., Chandrika, K.N., Padma, N., Harsha, H.C., Yatish, A.J., Kavitha, M.P., Menezes, M., Choudhury, D.R., Suresh, S., Ghosh, N., Saravana, R., Chandran, S, Krishna, S., Joy, M., Anand, S.K., Madavan, V., Joseph, A., Wong, G.W., Schiemann, W.P., Constantinescu, S.N., Huang, L.L., Khosravi-Far, R., Steen, H., Tewari, M., Ghaffari, S., Blobe, G.C., Dang, C.V., Garcia, J.G.N., Pevsner, J., Jensen, O.N., Roepstorff, P., Deshpande, K.S., Chinnaiyan, A.M., Hamosh, A., Chakravarti, A., and Pandey, A. Development of human protein reference database as an initial platform for approaching systems biology in humans. Genome Res 13, 2363, 2003.

153. Le Guéhennec, L., Layrolle, P., and Daculsi, G. A review of bioceramics and fibrin sealant. Eur Cell Mater 8, 1, 2004.

154. Liao, S., Wang, W., Uo, M., Ohkawa, S., Akasaka, T., Tamura, K., Cui, F., and Watari, F. A three-layered nano-carbonated hydroxyapatite/collagen/PLGA composite membrane for guided tissue regeneration. Biomaterials 26, 7564, 2005.

155. Shibata, Y., Yamamoto, H., and Miyazaki, T. Colloidal $\beta$-tricalcium phosphate prepared by discharge in a modified body fluid facilitates synthesis of collagen composites. J Dent Res 84, 827, 2005. 
156. Kim, H.W., Song, J.H., and Kim, H.E. Nanoriber generation of gelatin-hydroxyapatite biomimetics for guided tissue regeneration. Adv Func Mater 15, 1988, 2005.

157. Chen, M.H., Chen, P.R., Chen, M.H., Hsieh, S.T., Huang, J.S., and Lin, F.H. An in vivo study of tricalcium phosphate and glutaraldehyde crosslinking gelatin conduits in peripheral nerve repair. J Biomed Mater Res B 77B, 89, 2006.

158. Kulbatski, I., Cook, D.J., and Tator, C.H. Calcium entry through L-type calcium channels is essential for neurite regeneration in cultured sympathetic neurons. J Neurotrauma 21, 367, 2004.

159. Chang, Y.L., Stanford, C.M., and Keller, J.C. Calcium and phosphate supplementation promotes bone cell mineralization: implications for hydroxyapatite (HA)-enhanced bone formation. J Biomed Mater Res 52, 270, 2000.

160. Kirkham, J., Firth, A., Vernals, D., Boden, N., Robinson, C., Shore, R,C, Brookes SJ, and Aggeli, A. Self-assembling peptide scaffolds promote enamel remineralization. J Dent Res 86, 426, 2007.

161. Slotte, C., Lundgren, D., and Sennerby, L. Bone morphology and vascularization of untreated and guided bone augmentation-treated rabbit calvaria: evaluation of an augmentation model. Clin Oral Implant Res 16, 228, 2005.

162. Lundgren, D., Sennerby, L., Falk, H., Friberg, B., and Nyman, S. The use of a new bioresorbable barrier for guided bone regeneration in connection with implant installationcase-reports. Clin Oral Implant Res 5, 177, 1994.

163. Nyman, R., Sennerby, L., Nyman, S., and Lundgren, D. Influence of bone marrow on membrane-guided bone regeneration of segmental long-bone defects in rabbits. Scand J Plast Reconstr Surg Hand Surg 35, 239, 2001.

164. Thorwarth, M., Schultze-Mosgau, S., Wehrhan, F., Srour, S., Wiltfang, J., Neukam, F.W., and Schlegel, K.A. Enhanced bone regeneration with a synthetic cell-binding peptidein vivo results. Biochem Biophys Res Commun 329, 789, 2005.

165. Nguyen, H., Qian, J.J., Bhatnagar, R.S., and Li, S. Enhanced cell attachment and osteoblastic activity by P-15 peptidecoated matrix in hydrogels. Biochem Biophys Res Commun 311, 179, 2003.

166. Graham, F.L., and Vandereb, A.J. New technique for assay of infectivity of human adenovirus 5 DNA. Virology 52, 456, 1973.

167. Olton, D., Li, J., Wilson, M.E., Rogers, T., Close, J., Huang, L., Kumta, P.N., and Sfeir, C. Nanostructured calcium phosphates (NanoCaPs) for non-viral gene delivery: influence of the synthesis parameters on transfection efficiency. Biomaterials 28, 1267, 2007.

168. Barroug, A., and Glimcher, M.J. Hydroxyapatite crystals as a local delivery system for cisplatin: adsorption and release of cisplatin in vitro. J Orthop Res 20, 274, 2002.

169. Guicheux, J., Grimandi, G., Trecant, M., Faivre, A., Takahashi, S., and Daculsi, G. Apatite as carrier for growth hormone: in vitro characterization of loading and release. J Biomed Mater Res 34, 165, 1997.

170. Mizushima, Y., Ikoma, T., Tanaka, J., Hoshi, K., Ishihara, T., Ogawa, Y., and Ueno, A. Injectable porous hydroxyapatite microparticles as a new carrier for protein and lipophilic drugs. J Contr Rel 110, 260, 2006.

171. Yuan, H.P., de Bruijn, J.D., Zhang, X.D., van Blitterswijk, C.A., and de Groot, K. Use of an osteoinductive biomaterial as a bone morphogenetic protein carrier. J Mater Sci Mater Med 12, 761, 2001.

172. Fan, Y., Sun, Z., Wang, R., Abbott, C., and MoradianOldak, J. Enamel inspired nanocomposite fabrication through amelogenin supramolecular assembly. Biomaterials 28, 3034, 2007.

173. Kretlow, J.D., and Mikos, A.G. Review: mineralization of synthetic polymer scaffolds for bone tissue engineering. Tissue Eng 13, 927, 2007.

174. Azevedo, H.S., Leonor, I.B., Alvesa, C.M., and Reis, R.L. Incorporation of proteins and enzymes at different stages of the preparation of calcium phosphate coatings on a degradable substrate by a biomimetic methodology. Mater Sci Eng C 25, 169, 2005.

175. Leonor, I.B., Azevedo, H.S., Alves, C.M., and Reis, R.L. Effects of the incorporation of proteins and active enzymes on biomimetic calcium-phosphate coatings. In: Bioceramics. $15,97,2003$.

176. Stupp, S.I., and Ciegler, G.W. Organoapatites-materials for artificial bone .1. Synthesis and microstructure. J Biomed Mater Res 26, 169, 1992.

177. Liu, Y., Hunziker, E.B., Randall, N.X., de Groot, K., and Layrolle, P. Proteins incorporated into biomimetically prepared calcium phosphate coatings modulate their mechanical strength and dissolution rate. Biomaterials 24, 65, 2003.

178. Berna, F., Matthews, A., and Weiner, S. Solubilities of bone mineral from archaeological sites: the recrystallization window. J Archaeol Sci 31, 867, 2004.

179. Arnold, S., Plate, U., Wiesmann, H.P., Stratmann, U., Kohl, H., and Höhling, H.J. Quantitative analyses of the biomineralization of different hard tissues. J Microscopy 202, 488, 2001.

180. Sikavitsas, V.I., Temenoff, J.S., and Mikos, A.G. Biomaterials and bone mechanotransduction. Biomaterials 22, 2581, 2001.

181. Du, C., Cui, F.Z., Feng, Q.L., Zhu, X.D., and de Groot, K. Tissue response to nano-hydroxyapatite/collagen composite implants in marrow cavity. J Biomed Mater Res 42, 540, 1998.

182. Doi, Y., Horiguchi, T., Moriwaki, Y., Kitago, H., Kajimoto, T., and Iwayama, Y. Formation of apatite-collagen complexes. J Biomed Mater Res 31, 43, 1996.

183. Banks, E., Nakajima, S., Shapiro, I.C., Tilevitz, O., Alonzo, J.R., and Chianelli, R.R. Fibrous apatite grown on modified collagen. Science 198, 1164, 1977.

184. Segvich, S., Smith, H.C., Luong, L.N., and Kohn, D.H. Uniform deposition of protein incorporated mineral layer on three-dimensional porous polymer scaffolds. J Biomed Mater Res B Appl Biomater 84B, 340, 2008.

185. Liu, Y., de Groot, K., and Hunziker, E.B. BMP-2 liberated from biomimetic implant coatings induces and sustains direct ossification in an ectopic rat model. Bone 36, 745, 2005.

186. Gonzalez-McQuire, R., Walsh, D., Hall, S., Mann, S., Green, D., Oreffo, R.O.C., and Chane-Ching, J.Y. Fabrication of hydroxyapatite sponges by dextran sulphate/amino acid templating. Biomaterials 26, 6652, 2005.

187. Zhang, S.G. Emerging biological materials through molecular self-assembly. Biotechnol Adv 20, 321, 2002.

188. Hartgerink, J.D., Beniash, E., and Stupp, S.I. Peptideamphiphile nanofibers: a versatile scaffold for the preparation of self-assembling materials. Proc Natl Acad Sci USA 99, 5133, 2002.

189. Hartgerink, J.D., Beniash, E., and Stupp, S.I. Self-assembly and mineralization of peptide-amphiphile nanofibers. Science 294, 1684, 2001.

190. Semino, C.E. Self-assembling peptides: from bio-inspired materials to bone regeneration. J Dent Res 87, 606, 2008. 
191. Sargeant, T.D., Guler, M.O., Oppenheimer, S.M., Mata, A., Satcher, R.L., Dunand, D.C., and Stupp, S.I. Hybrid bone implants: self-assembly of peptide amphiphile nanofibers within porous titanium. Biomaterials 29, 161, 2008.

192. Vauthey, S., Santoso, S., Gong, H., Watson, N., and Zhang, S. Molecular self-assembly of surfactant-like peptides to form nanotubes and nanovesicles. Proc Natl Acad Sci USA 99, 5355, 2002.

193. Santoso, S.S., Vauthey, S., and Zhang, S.G. Structures, function and applications of amphiphilic peptides. Curr Opin Colloid Interface Sci 7, 262, 2002.

194. Gilbert, M., Giachelli, C.M., and Stayton, P.S. Biomimetic peptides that engage specific integrindependent signaling pathways and bind to calcium phosphate surfaces. J Biomed Mater Res A 67A, 69, 2003.

195. Gilbert, M., Shaw, W.J., Long, J.R., Nelson, K., Drobny, G.P., Giachelli, C.M., and Stayton, P.S. Chimeric peptides of statherin and osteopontin that bind hydroxyapatite and mediate cell adhesion. J Biol Chem 275, 16213, 2000.

196. Sawyer, A.A., Weeks, D.M., Kelpke, S.S., McCracken, M.S., and Bellis, S.L. The effect of the addition of a polyglutamate motif to RGD on peptide tethering to hydroxyapatite and the promotion of mesenchymal stem cell adhesion. Biomaterials 26, 7046, 2005.

197. Sawyer, A.A., Hennessy, K.M., and Bellis, S.L. The effect of adsorbed serum proteins, RGD and proteoglycan-binding peptides on the adhesion of mesenchymal stem cells to hydroxyapatite. Biomaterials 28, 383, 2007.
198. Tye, C.E., Hunter, G.K., and Goldberg, H.A. Idenfication of the type I collagen-binding domain of bone sialo sialoprotein and characterization of the mechanism of interaction. J Biol Chem 280, 13487, 2005.

199. Wuttke, M., Muller, S., Nitsche, D.P., Paulsson, M., Hanisch, F.G., and Maurer, P. Structural characterization of human recombinant and bone-derived bone sialoprotein. Functional implications for cell attachment and hydroxyapatite binding. J Biol Chem 276, 36839, 2001.

Address reprint requests to: Rui L. Reis, Ph.D.

3B's Research Group-Biomaterials, Biodegradables, and Biomimetics

Department of Polymer Engineering

University of Minho

AvePark, Zona Industrial da Gandra

S. Cláudio do Barco

Apartado 4152

4806-909 Caldas das Taipas-Guimarães Portugal

E-mail: rgreis@dep.uminho.pt

Received: February 22, 2008 Accepted: August 4, 2008 

This article has been cited by:

1. Devendra K. Dubey, Vikas Tomar. 2010. Role of Molecular Level Interfacial Forces in Hard Biomaterial Mechanics: A Review. Annals of Biomedical Engineering 38:6, 2040-2055. [CrossRef]

2. Sheeny K. Lan Levengood, Samantha J. Polak, Matthew B. Wheeler, Aaron J. Maki, Sherrie G. Clark, Russell D. Jamison, Amy J. Wagoner Johnson. 2010. Multiscale osteointegration as a new paradigm for the design of calcium phosphate scaffolds for bone regeneration. Biomaterials 31:13, 3552-3563. [CrossRef]

3. N. M. Alves, I. B. Leonor, H. S. Azevedo, R. L. Reis, J. F. Mano. 2010. Designing biomaterials based on biomineralization of bone. Journal of Materials Chemistry 20:15, 2911. [CrossRef]

4. Jun-Hyeog Jang, Oscar Castano, Hae-Won Kim. 2009. Electrospun materials as potential platforms for bone tissue engineering $\square$. Advanced Drug Delivery Reviews 61:12, 1065-1083. [CrossRef] 